\title{
GERINCALAK ÉS IZOMAKTIVITÁS EGYÜTTES VÁLTOZÁSA TÖRZSERŐ-TESZTEK SORÁN FIATAL KOSÁRLABDÁZÓK KÖRÉBEN
}

\author{
Petró Bálint ${ }^{1}$, Gál-Pottyondy Anna ${ }^{2}$, Kiss Rita M. ${ }^{1}$ \\ ${ }^{1}$ Budapesti Mûszaki és Gazdaságtudományi Egyetem, Mechatronika, Optika és Gépészeti \\ Informatika Tanszék \\ ${ }^{2}$ Testnevelési Egyetem
}

rita.kiss@mogi.bme.hu

DOI: $10.17489 /$ biohun/2019/1/02

\begin{abstract}
Absztrakt
A mindennapi és a sportéletben egyaránt fontos a törzsizmok és más testtartásért felelôs izmok megerôsítése és egyensúlyának biztosítása. A testtartás izmainak tesztelésére jól alkalmazható a plank-teszt, mely a fekvőtámaszhoz hasonló, csak hajlított alkartámaszban kezdődik és ennek a helyzetnek az egy percig történő megtartása. Előnye, hogy könnyen elvégezhető és nem igényel eszközt, ugyanakkor a teszt kiértékelése leggyakrabban csak szubjektíven, szemrevételezéssel történik. Ezért kialakítottunk egy új mérési protokollt a gerinc alakjának és az izomaktivitás változásának egyidôben való követésére.

A protokoll tesztelésére 11 fiú kosárlabdázó (13-17 év) részvételével végeztünk méréseket; a feladat egy percig tartó plank-teszt volt. A gerinc alakját tövisnyúlványokra helyezett jelölők optikai követésével állapítottuk meg, melyből a gerincgörbületi szögek (kyphosis és lordosis) számíthatók minden időpontra. Felületi elektromiográfiával mértük 11 izom aktivitását; a medián frekvencia csökkenésének számításával megállapítottuk az izomfáradás mértékét.

A gerincszögek változása a gyakorlat elsô és utolsó 10 másodperce között minden esetben a kyphosis (jellemzően nagymértékú) növekedését mutatta; a lordosis vagy kismértékben csökkent, vagy nagymértékben nốtt. Ez azt mutatja, hogy a plank-teszt során az egyes résztvevôk különbözô módokon fáradnak el, melyek indikálhatják különböző stabilizáló izmok gyengeségét.

Az EMG medián frekvenciája a gyakorlat során jellemzően vagy közel állandó, vagy egyenletesen csökkenő volt a vizsgált izmokban (szignifikánsan fáradt a m. gluteus maximus, az erector spinae iliocostalis, a rectus abdominis longus és az obliquus externus abdominis), ám néhány izom mutatott hullámzó aktivitást is. Szignifikáns korrelációt a m. rectus femoris fáradása és a gerincgörbületek növekedése között találtunk. További kutatási lehetőséget ad a protokoll elvégzése homogén életkorú, különböző sportot ûzô csoportok részvételével.
\end{abstract}

Kulcsszavak: elektromiográfia, izomfáradás, gerincgörbületek, törzserő, core izmok

\section{CONCURRENT CHANGES IN SPINAL CURVATURES AND MUSCLE ACTIVITIES DURING POSTURAL MUSCLE TESTING AMONG YOUNG BASKETBALL PLAYERS}

\begin{abstract}
Strengthening postural and core muscles and ensuring their balance is vital in everyday and sports life as well. For functional testing of postural muscles, the plank-test can be used which consists of holding the plank (prone bridge) position for an amount of time, e.g. 1 minute. This test is easy to administer and
\end{abstract}


requires no equipment; however, evaluation is usually done only visually, in a subjective manner. This motivated the development of a novel measurement protocol simultaneously recording spinal curvatures and muscle activations.

Testing of the protocol was done involving 11 young boy basketball players (aged 13-17 years); the task was holding the plank position for one minute. Spinal curvatures were recorded by placing optical motion capture markers on eleven spinous processes from which the curvature angles (kyphosis and lordosis) could be obtained for each video frame. Surface electromyography was used to measure activities of 11 muscles; muscle fatigue was obtained by calculating the decrease in median frequency of the electric signal.

The changes in curvature comparing the first and last 10 seconds of the tests showed for every participant a (usually large) increase in kyphosis values; lordosis values either decreased to a small extent or increased to a large extent. This shows that during the plank-test, the fatiguing process is can differ among individuals which may indicate the lack in power of different postural muscles.

The median frequencies of EMG signals generally either stayed constant during the test or showed a steady decrease. Significant fatigue was detected for the $\mathrm{m}$. gluteus maximus, the erector spinae iliocostalis, the rectus abdominis longus and the obliquus externus abdominis. Some muscles showed a fluctuation in activity. Comparing muscle fatigue and curvature changes, only the m. rectus femoris showed a significant correlation. Further research should be carried out involving a more homogeneous participant group and participants from other sports as well.

Keywords: electromyography, muscle fatigue, spinal curvatures, core strength, core muscles.

\section{Bevezetés}

A törzsizmoknak és a testtartásért felelős egyéb izmoknak szinte minden mozgás közben aktív, stabilizáló szerepük is van. Ezen izmok megfelelő erőállóképessége és izomegyensúlya egyaránt fontos. Elengedhetetlen a törzsizmok megerősítése a helyes testtartás és a magas terhelhetôség érdekében. Erôs törzsizomzattal gyorsabban, pontosabban tudják a mozgásokat végrehajtani a sportolók. Magasabb szintú sporteredmény eléréséhez elengedhetetlen a súlyzós edzések edzésprogramba való beépítése. Ennek azonban szigorú előfeltételei és szabályai vannak, mint a csontosodási folyamatok befejeződése, a közel végleges testarányok kialakulása, a gyakorlatok saját testsúllyal történô tökéletes kivitelezése.

A csont- és izomrendszer egészséges fejlődését megtartó, elősegítő edzések tervezéséhez szükséges a sportolók aktuális fiziológiás állapotának ismerete. A törzsizmok csökkent állóképessége és az alsó végtag fáradásos sérülései szignifikánsan összefüggnek. ${ }^{1}$ Ugyanakkor Nesser és munkatársai szignifikáns, de nem erôs összefüggést találtak a törzserô és az általános erôt mérô változók között sprintfutás, ingafutás, guggolás és fekvenyomás gyakorlatokat vizsgálva. ${ }^{2}$ Kiemelik, hogy a törzs izmai egy egységet alkotnak, így egységben, több izomcsoportot együttesen vizsgálva célszerû összehasonlítani azok mûködését sportspecifikus tesztekkel. A gerinc és az azt körülvevő izmok állapotának felmérése a sérülések rizikójának becslésénél és az általános terhelhetôség megállapításánál is fontos szerepet játszik. ${ }^{2}$

A törzsizmok erejének tesztelésére elterjedten használnak statikus, izometrikus terhelést jelentő teszteket, gyakorlatokat. ${ }^{3-6}$ Ezen egyszerû tesztek sportéletben használatának gyakor- 
lati előnye, hogy könnyen megismételhetők és alacsony eszközigényûek. Sok esetben azonban csak a feladatot végeztetô gyógytornász vagy más szakember megtekintése alapján értékelik a tesztet, tehát egyelőre hiányoznak a feladatok objektív, mûszeres kiértékelési lehetôségei. Népszerûségük miatt azonban tudományos kutatások is vizsgálták már ezeket a gyakorlatokat. A törzserőtesztek kiértékelésében a mozgás kinematikai mérése mellett az izomaktivitás felületi elektromiográfiás (EMG) vizsgálatát alkalmazzák. Sportolók törzsizomzatának aktuális állapotának megfelelő és hiteles felmérésére alkalmas például a módosított Matthias-teszt ${ }^{3}$ vagy a plank-teszt is. ${ }^{4-6}$ A plank-pozíció egyperces megtartása a core izomcsoportok állóképességi munkáját igénylő saját testsúllyal történő feladat. Ugyanakkor Tillaar és munkatársa a rectus abdominis és az external obliqe izmok esetében hasonló aktivitást figyelt meg a hat ismétléses maximális guggolás és az egyperces plank gyakorlatok kivitelezése közben.?

Az utánpótlás korú sportolóknak nemcsak a növekvô edzés- és versenyterheléssel kell megküzdeniük, hanem testük gyors ütemû változásával, növekedésével is. Serdülőkorban nagy figyelmet kell szentelni a kondicionális képességek megfelelő fejlesztésére. A hosszútávú és magas szintû sporteredmény eléréséhez elengedhetetlen, hogy a sportágspecifikus erôsítések mellett helyet kapjanak a helyes testtartást és izomegyensúlyt elôsegítő feladatok is. Jellemzően az aszimmetrikus terheléssel járó sportágak sportolói a veszélyeztettek, azonban a nem tipikus testalkatot igénylő sportokat is, mint például a kosárlabdát, kiemelten kell kezelni. Lark és munkatársai megmutatták, hogy a plank-teszt alkalmas aktív kosárlabdázók törzsizomzatának felmérésére. ${ }^{8}$ Ezért célul tûztük ki egy vizsgálati protokoll kifejlesztését és tesztelését, amely lehetôvé teszi a plank-teszt objektív kiértékelését. A testtartás objektív méréséhez a gerinc alakját, és annak változását mérjük; emellett vizsgálni szeretnénk a pozíció megtartásában leginkább szerepet játszó izmok fáradását is. Hasonló elrendezésû méréseket nemrégiben kezdtek kutatásokban használni. ${ }^{9}$ A gerinc alakjának folytonos követése lehetséges fényvisszaverố jelölők (markerek) bőrre való felhelyezésével. ${ }^{10}$ A csigolyatövisnyúlványokra helyezett jelölôk pozícióját optikai mozgáskövetố (motion capture, MoCap) rendszerrel meghatározhatjuk minden képkockán; az ezekre illesztett görbe közelíti a gerincoszlop alakját. Ezzel a módszerrel abszolút gerincgörbületi értékek csak bizonytalansággal állapíthatók meg, azonban alkalmas a görbületi szögértékekben történő változások meghatározására. ${ }^{10,11}$ A módszert korábban megvalósítottuk a BME MOGI Tanszék Mozgásvizsgáló Laboratóriumában. ${ }^{12}$ A gerincgörbületek mérésével párhuzamosan érdekesek lehetnek az egyes izmok fáradásai is. A fáradás mértékének megállapításához az EMG-jelek megfelelő szûrése ${ }^{13}$ után az elektromos jel medián frekvenciáját számíthatjuk, amelynek csökkenése indikálja az izomfáradást. ${ }^{14,15}$

Jelen kutatás célja egy olyan vizsgálati módszer kidolgozása, amellyel egyidejűleg meghatározható a gerinc alakjának változása és az ehhez kapcsolódó izmok aktivitása, fáradása. A módszer kiterjeszthető egyéb ízületek szögének változására, így bármilyen mozgás vizsgálatára is. Mostani, előzetes méréseinket fiatal kosárlabdázók körében végeztük el.

\section{Módszerek}

\section{Résztvevôkk}

Méréseinken a Szolnoki Kosárlabda Akadémia 11 fiú sportolója vett részt. A résztvevők életkora 13-17 év (átlag 14,6 év), testmagassága 153-199 cm (átlag $181 \mathrm{~cm}$ ), testtömege 37-81 kg (átlag 63,1 kg). Méréseinket a BME MOGI Tanszékének Mozgásvizsgáló laboratóriumá- 
ban végeztük, három alkalomra elosztva. A mérés elôtt kikérdeztük a résztvevőket múltbéli és jelenlegi sportolási szokásaikról, aktuális sportterhelésükrôl, a csapatban betöltött pozíciójukról, valamint aktuális állapotukról: sportoltak-e előző nap, milyen állapotban érzik magukat. Néhány résztvevő enyhe izomlázról számolt be előző napi sportolás miatt.

\section{Mérési protokoll}

Az érzékelők és jelölők megfelelő felhelyezése és tesztelése után a résztvevő a MoCap rendszer mérôterében, a padlón elhelyezett polifoam szőnyegen elhelyezkedik. Felveszi a fekvőtámaszhoz hasonló plank-pozíciót (1. ábra), behajlított karokkal, alkarjára támaszkodva; az alkarok párhuzamosak a gerinccel. A test egyenes; a tarkó, a vállak közti háti szakasz, a keresztcsont, a térdek és a bokák egy vonalon helyezkednek el. Az instrukció: A szabályos plank-pozíciót tartsa meg egy percig. A szabályos pozíció felvételével indult a 60 s-os mérés. A feladat megkezdése után már nem kapott további instrukciót a játékos, még abban az esetben se, ha már nem volt szabályos a feladat kivitelezése.

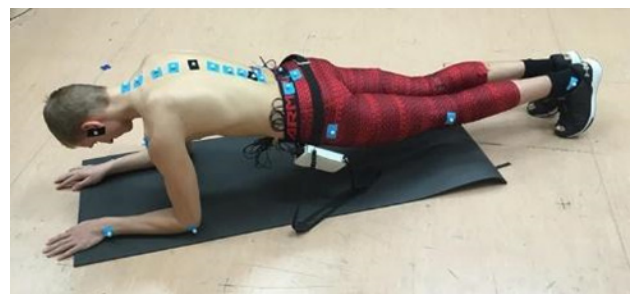

1. ábra. Plank-pozíció, mérési elrendezés

\section{Gerinc alakjának mérése}

A gerinc alakjának és a test pozíciójának méréséhez retroreflektív markereket helyeztünk el a résztvevőn. A markerek térbeli pozícióját egy 18 kamerás OptiTrack ${ }^{\circledR}$ Motive (NaturalPoint Inc., Oregon, USA) mozgásvizsgáló (MoCap) rendszerrel követtük nyomon, $100 \mathrm{~Hz}$-es mintavételezéssel. Összesen 10 csigolya processus spinosusait jelöltük meg ${ }^{12}$ (lásd 1. ábrán), ezek: C6, T1, T4, T6, T8, T10, T12, L2, L4 és L5. További markereket helyeztünk el a sacrumon, a jobb- és baloldali fültövön, vállcsúcson, könyök és csukló laterális bütykén, a nagytomporokon, a térd és boka laterális oldalain, amelyek a jobb követhetôség biztosították, adataikat nem használtuk fel.

Az adatfeldolgozás során a mért markerpozíciókat aluláteresztő szûrôvel, $6 \mathrm{~Hz}$-es vágási frekvenciával simítottuk. A gerincalak meghatározásához a 10 tövisnyúlványon lévő markerre térbeli spline görbét illesztettünk a négyzetes hibaérték minimalizálásával. A lumbális lordózis (LL) és a thorakális kyphosis (TK) szögek definíciószerüen a mért pontokra illesztett görbe T1, T12, L5 processus spinosusokat reprezentáló pontoknál behúzott érintôk által bezárt szögek.

Izomaktivitás mérése felületi elektromiográfiával - vizsgált izmok, mérési protokoll, jelfeldolgozás

Az izomaktivitás Telemyo típusú felületi, bipoláris EMG adatgyújtô berendezéssel (Noraxon Inc., Scottsdale, AZ, USA) történt. Az adatgyưjtő 16 vezetékes csatornát használ, valamint elérhető hozzá egy rádiófrekvenciás adóvevő is. Az adóvevő párja egy mobilis felvevő egység, amelyhez 16 csatorna csatlakoztatható. A felvevőben tízszeres erôsítés található, a jel/zaj viszony $65 \mathrm{~dB}$-nél nagyobb. A felvevő összegzett szûrési sávja 0-1150 Hz; a mintavételezési frekvencia $2 \mathrm{kHz}$. Az adatgyűjtő a hozzá tartozó gyári szoftver segítségével kapcsolódik a mérést vezérlő számítógéphez.

A bipoláris, felületi elektródákat a $\mathrm{SENIAM}^{16}$ ajánlásait követve helyeztük el. A gerincen eredő izmok közül két felületes izmot vizsgáltunk, ezek a m. erector spinae longissimus és 
a m. erector spinae iliocostalis, melyek a gerinc legfőbb feszítô izmai. A hasizmok közül szintén kettôt vizsgáltunk, ezek a m. obliquus externus abdominis és a m.rectus abdominis, melyek fô feladata a hasûri nyomás fenntartása és az alsó és felsố testfél izomláncai közötti kapcsolat kialakítása. A medencefenék izmai közül a m. gluteus maximus és m. gluteus medius izmokat mértük. Előbbi, a maximus a csípőízület feszítője, ezáltal az egyenes testtartás legfő́bb biztosítéka, míg a medius a comb abductora és belsô rotátora, így fekvôtámaszban is rögzítő szerepe van. A térdízület mozgatását végző izmok közül a m. rectus femoris-t (csípőízületi flexio), a m. adductor longus-t (comb adductora) és a m. biceps femoris-t (térdízület flexio) mértük. A bokaízület mozgatásában részt vevô izmok közül a m. tibialis anterior-t (a lábfejet bokából lábháti irányba hajlítja) és a $\mathrm{m}$. gastrocnemius medialis-t (térd flexio, boka plantarflexio) mértük. Erről a mérési elrendezésrôl korábban beszámoltunk. ${ }^{17}$ A földpontot a térdkalácson helyeztük el.

A használt elektródák Ambu gyártmányú (Ballerup, Dánia) „BlueSensor N” típusú, egyszer használatos csecsemókre méretezett EKG-elektródák voltak, melyek ezüst/ ezüstklorid anyagúak. Két egymás mellé helyezett elektróda közt $2 \mathrm{~cm}$ távolság volt. Az elektródák felhelyezése előtt a területet frissen leborotváltuk, a legfinomabb dörzspapírral a bôr felületét lecsiszoltuk, majd egy alkoholos bőrfertôtlenítő folyadék és vatta segítségével a bőrön található maradék szennyeződést is eltávolítottuk. Az elektródákat és azokat a felvevővel összekötő kábeleket leukoplaszttal rögzítettük a bőrhöz. A kontaktus ellenôrzésére az egyes izmok megfeszítésére, terhelésére kértük a résztvevő́t a SENIAM modellben megadott testhelyzetekben.

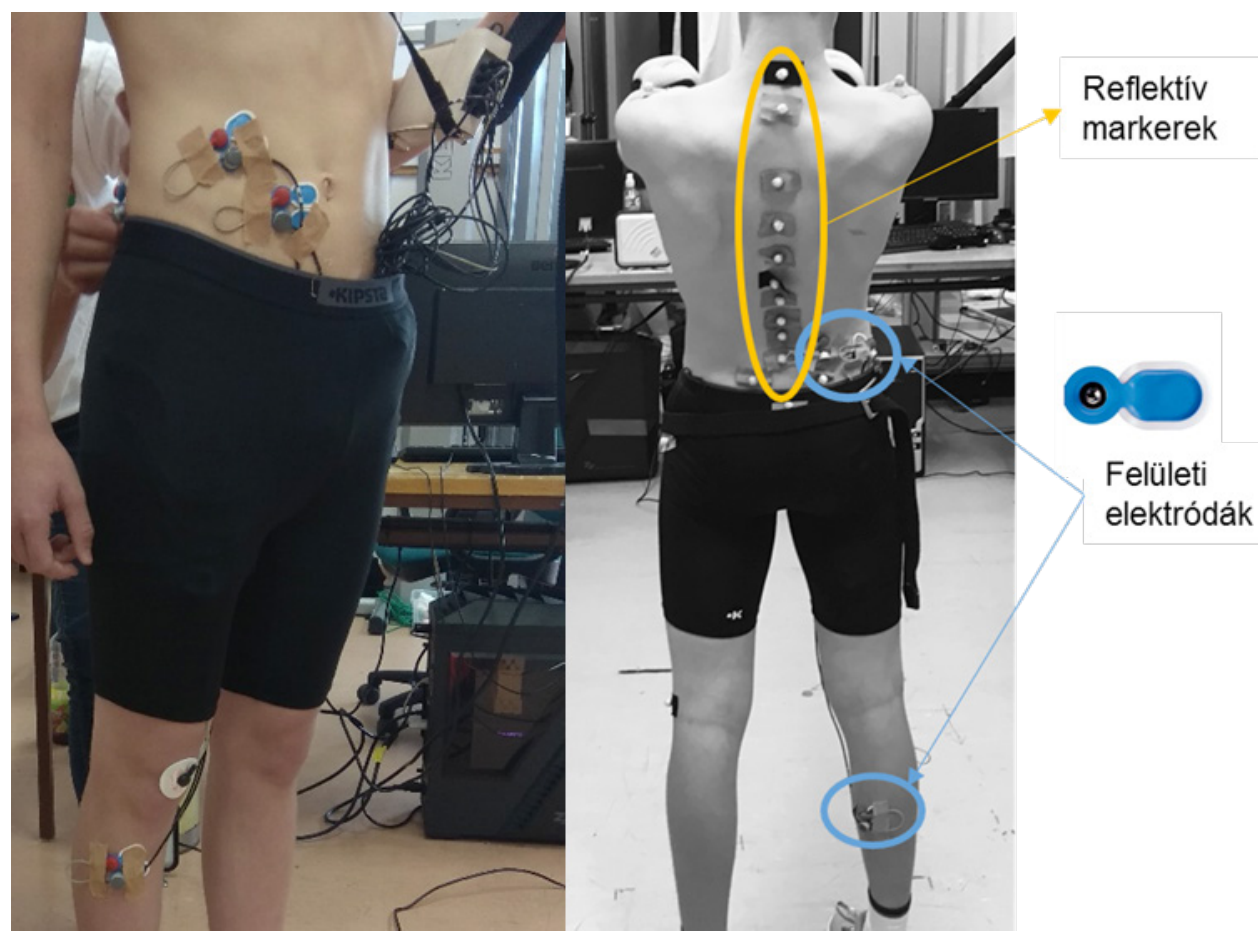

2. ábra. Felhelyezett felületi elektródák és reflektív markerek 
Az EMG-jelek, mint minden fiziológiás elektromos jel mérése során zajokkal terheltek. Az alacsony frekvenciás zajok $(0-20 \mathrm{~Hz})$ az elektróda, a bőr vagy az elektródához csatlakozó kábelek elmozdulásából ered. Ezek a frekvenciakomponensek különösen instabilak, mivel ezeket a motoregységek tüzelési sebességének kvázi-véletlenszerú jellege befolyásolja. A jel összetevôinek instabil jellegéből adódóan tanácsos ezeket zajnak tekinteni és eltávolítani őket a jelbôl. A helyiségben lévő hálózati 50 Hz-es frekvencia szintén könnyen megjelenik a mért jelben. Az is ismert, hogy $500 \mathrm{~Hz}$ fölött már nem számíthatunk izomaktivitás eredetû EMG-jelre, hiszen ennél sûrúbben tipikusan nem fordulnak elő akciós potenciálok. A törzs izmaira tett elektródák sok esetben érzékelik a szívből jövő EKG jeleket, ami az izmok tekintetében szintén zajnak tekinthetô, így azok kiszûrése is indokolt. Ennek megfelelően a mért elektromos jeleken szûréseket végeztünk: az EKG-jel kiszûrését, felüláteresztő szűrést 20 Hz-es vágási frekvenciával; sávzáró szűrést 45$55 \mathrm{~Hz}$ között, illetve aluláteresztő szűrést 500 Hz-es vágási frekvenciával.

A frekvenciatartományi szúrések elvégzése után a mért jel további, tüskeszerú múhibákkal volt terhelt. Ezek ritkán, csak egymástól több másodpercnyi távolságra helyezkedtek el, és mindössze 4-8 minta hosszúak voltak, azonban amplitúdóban a jel többi részének sokszorosát jelentették és a medián frekvencia számítását irreálisan befolyásolták. Ezeket a tüskéket hibás mért értéknek tekintve, nullával helyettesítettük.

A MoCap rendszerrel való mérés idóbeli szinkronizálásához, a mérés kezdetének illesztéséhez a MoCap rendszer megfelelő kezelőszervén lévố szinkronizáló kimenetet vezetékkel összekötöttük az EMG adatgyújtő egyik csatornájával. A vezetéken alapértelmezésben alacsony feszültségszintú jel van, mely a MoCap rendszer felvételének indításakor magas szintre ugrik, így ez az él egyértelmúen jelöli az indítást.

\section{Vizsgált paraméterek}

Az izomfáradás számszerû́ jellemzésére az EMG-vel mérhetô izomaktivitás medián frekvenciájának megváltozását használtuk. ${ }^{15}$ Az egyenként 60 másodperces felvételeket $3 \mathrm{~s}$ hosszú, egymással $50 \%$-ban átfedő szakaszokra bontva számítottuk a medián frekvenciát, a szakaszok középpontjához rendelve. A $60 \mathrm{~s}$ hosszú felvételekre kapott medián frekvencia értékekre lineáris regressziót illesztettünk. Így a regressziós egyenes meredeksége mutatja a medián frekvencia átlagos csökkenését, esetlegesen növekedését. Ezt a csökkenő meredeksé-

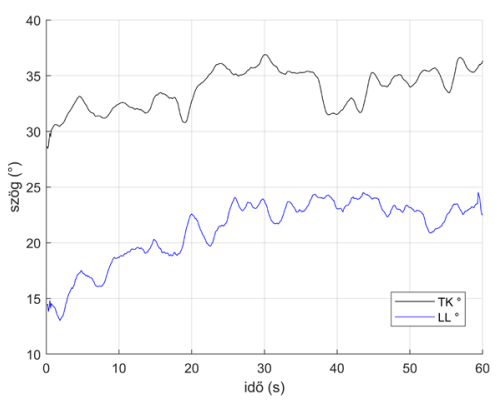

3. ábra. Gerincalak változása plank-teszt során egy résztvevőre 

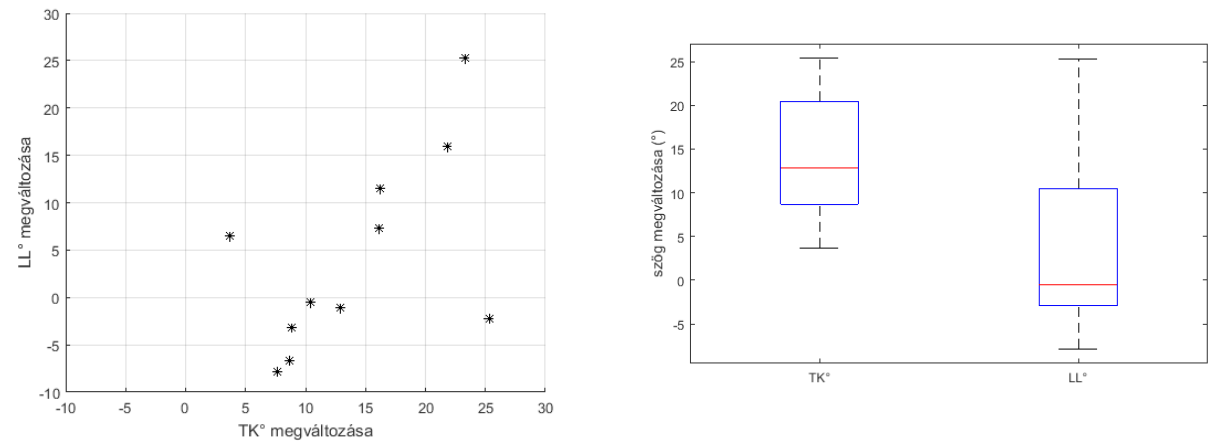

4. ábra. Szórásdiagram és dobozábra a TK és LL szögek megváltozásáról a plank-teszt eleje és vége között a csoportban

get tekintjük izomfáradásnak. Az egyes izmok összehasonlíthatósága érdekében a medián frekvenciákat azok maximumával normáltuk 0 és 100\% közé, így az egyenes meredekségének számértéke is így értelmezendő. Negatívabb meredekség nagyobb mértékú izomfáradásnak felel meg.

A gerincalakot leíró két szög, a TK és LL értékeléséhez a 60 s hosszú plank gyakorlat alatt az elsố és utolsó 10 s-es szakaszon mért szögek átlagát és szórását hasonlítottuk össze, minden résztvevốt saját magával. A különbség statisz-
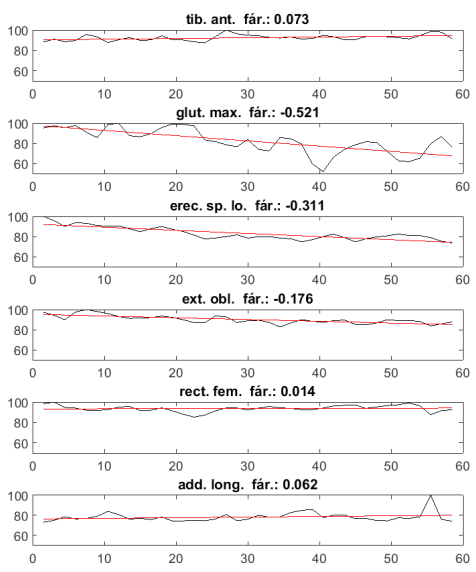

5. ábra. A vizsgált izmok mediánfrekvenciája plank-teszt során egy résztvevőre tikai szignifikanciáját Wilcoxon-féle elójeles rang-teszt alkalmazásával vizsgáltuk. Szintén összehasonlítottuk a TK és LL szög gyakorlat során történt megváltozását az egyes izmok fáradásával, itt Spearman-féle korrelációs együtthatót számítottunk.

\section{Eredmények}

A MoCap rendszer használatával a gerincalak a gyakorlat végzése során végig meghatározható (példa a 3. ábrán), amelyet videóként megtekintve értékelhetô a gerincben bekövet-
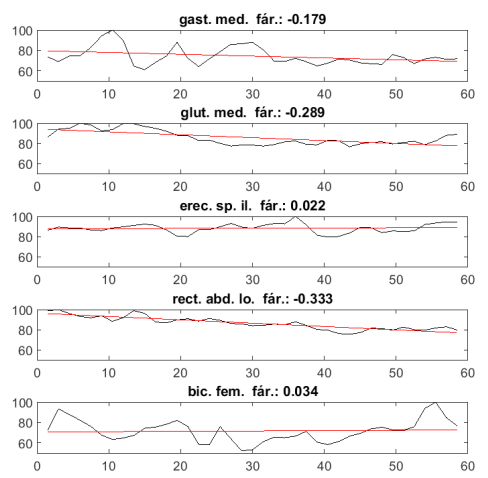


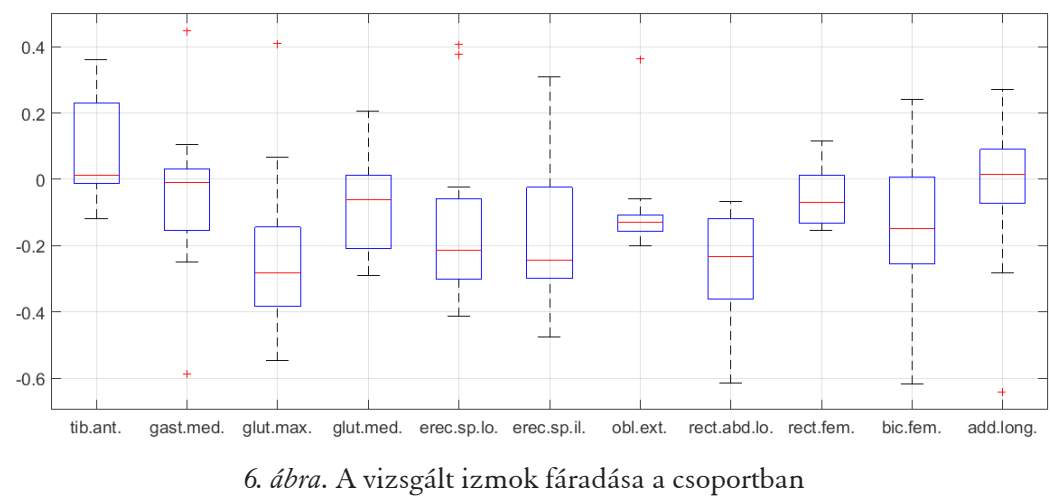

kező változás. Ez a gerincszögeket ábrázolva szintén követhetô (példa a 3. ábrán). A gerincszögek változása a gyakorlat első és utolsó 10 s-a között minden esetben a TK (jellemzốen nagymértékû) növekedését mutatta; az LL szög vagy kismértékben csökkent, vagy nagymértékben nôtt (4. ábra). A TK megváltozása erôsen szignifikáns $(\mathrm{p}<0,001)$, míg az LL megváltozása a kétféle viselkedés miatt nem szignifikáns $(\mathrm{p}=0,4659)$ a csoportban. A TK és LL megváltozása nagymértékben korrelált: rho $=0,57(\mathrm{p}=0,07)$, két erősen kiugró adatpont mellett (4. ábra).

Az EMG medián frekvenciája a gyakorlat során jellemzően vagy közel állandó, vagy egyenletesen csökkenő volt a vizsgált izmokban, ám néhány izom mutatott hullámzó aktivitást is (példa az 5. ábrán). A csoport tagjai közül leggyakrabban ilyen hullámzó aktivitást mutatott rendre a $\mathrm{m}$. gluteus maximus, a $\mathrm{m}$. gluteus medius, a m. gastrocnemius medialis és a m. biceps femoris.
$\mathrm{Az}$ egész csoportra vetítve az egyes izmok jellemző fáradását mutatja a 6. ábra; a statisztikai szignifikanciaértékeket az 1. táblázatban foglaltuk össze. Egyöntetûen fáradást mutatott a m. gluteus maximus $(\mathrm{p}=0.032)$, az erector spinae iliocostalis $(\mathrm{p}=0.102)$ és a rectus abdominis longus $(p=0.001)$, valamint kismértékben a m. obliquus externus abdominis $(p=0.054)$ is.

A gerincszögek megváltozása és az izmok fáradása között kevés szignifikáns korreláció volt felfedezhetô (2. táblázat). Szignifikáns korrelációt csak a m. rectus femoris és a m. gastrocnemius medialis mutatott. A m. rectus femoris esetében a korreláció negatív, azaz a nagyobb fáradás (csökkenô aktivitás) nagyobb szögváltozást eredményezett a gerincben. Ezzel szemben a m. gastrocnemius medialis pozitívan korrelált, azaz nagyobb aktivitás esetén a szögváltozás nagyobb volt. Feltételezhetôen ez a célzott testtartástól való eltérés miatt egy kompenzációs folyamatot jelez.

\begin{tabular}{|l|r|r|r|r|r|r|}
\hline izom & tib ant & gast med & glut max & glut med & erec sp lo & erec sp il \\
\hline p-érték & 0.240 & 0.465 & 0.032 & 0.123 & 0.240 & 0.102 \\
\hline izom & obl ext & rect abd lo & rect fem & bic fem & add lon & \\
\hline p-érték & 0.054 & 0.001 & 0.206 & 0.123 & 1.000 & \\
\hline
\end{tabular}

1. táblázat. A vizsgált izmok fáradásának szignifikanciája a csoportban 


\begin{tabular}{|l|r|r|r|r|r|r|}
\hline izom & tib ant & gast med & glut max & glut med & erec sp lo & erec sp il \\
\hline TK & $0.53^{*}$ & $0.77^{* *}$ & -0.02 & 0.21 & 0.46 & 0.45 \\
\hline LL & -0.06 & $0.55^{*}$ & -0.16 & 0.15 & 0.17 & 0.45 \\
\hline izom & obl ext & rect abd lo & rect fem & bic fem & add lon & \\
\hline TK & 0.44 & -0.35 & $-0.61^{* *}$ & 0.35 & -0.15 & \\
\hline LL & 0.14 & 0.11 & $-0.68^{* *}$ & 0.27 & 0.07 & \\
\hline
\end{tabular}

2. táblázat. Korrelációs együttható a gerincszögek megváltozása és az izmok fáradása között

$$
{ }^{*} \mathrm{p}<0.1,{ }^{* *} \mathrm{p}<0.05,{ }^{* * *} \mathrm{p}<0.01
$$

\section{Megbeszélés}

Jelen munka célja a a gerincgörbület változásának és a testtartásért felelős izmok fáradásának mérése volt egyperces plank-teszt során. A mozgáselemző rendszer felvételei alapján a processus spinosusok által leírt görbék változásait a két gerincgörbület (kyphosis és lordosis) formájában numerikusan rögzítettük, és a teszt eleje és vége közti pozíciókban lévô különbséget vizsgáltuk. Míg a TK minden esetben megnövekedett, az LL bizonyos résztvevőknél csökkent vagy stagnált, míg másoknál nagymértékben megnôtt. Felületi EMG-vel detektált jelek alapján az izmok aktivációs szintjének változását, illetve a kontrakciók során bekövetkező fáradást is kimutattuk. Szignifikáns fáradást mutatott a csoportot tekintve a m. gluteus maximus, az erector spinae iliocostalis, a rectus abdominis longus és az obliquus externus abdominis. Szignifikáns korrelációt a gerincgörbületek növekedése és az izomfáradás között csak a m. rectus femoris esetében találtunk.

Az egyperces plank-teszt során minden esetben észlelhetô volt jelentôsebb testtartásbeli változás (4. ábra), tipikusan a TK nagymértékú növekedése. A gyakorlat során az LL esetében egyénenként változóan előfordult a lágyéki hátszakasz kiegyenesedése, valamint a medence beejtésével a nagyfokú görbületi növekedés is (4. ábra). Ez azt mutatja, hogy a plank-teszt során az egyes résztvevők különböző módokon fáradnak el, melyek indikálhat- ják különböző stabilizáló izmok gyengeségét. Bohannon és munkatársai szintén kifáradásig végzett plank-teszt során a fáradás többféle megjelenését figyelték meg. ${ }^{18}$ A vizsgálati személyek ( $\mathrm{n}=103$ ) saját elmondás alapján 11 féle módon indokolták a gyakorlat abbahagyását. Elsố helyen szerepelt a remegés, második helyen a hátfájás, de megjelent többek között a has és a comb fáradása is. Ezért plank-teszt során a gerincgörbület mû́szeres regisztrálása segítség lehet a törzsizmok állapotfelmérésében. Czaprowski és munkatársai plank-teszt során a m. rectus abdominis, m. obliquus externus, $\mathrm{m}$. internal oblique/m. transversus abdominis izmok EMG aktivitását vizsgálták. ${ }^{19}$ Vizsgálataik során az m. obliquus externus izomnál

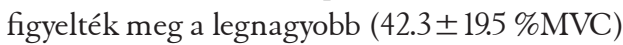
aktivitást. A m. rectus abdominis és a $\mathrm{m}$. internal oblique $/ \mathrm{m}$. transversus abdominis esetében jóval alacsonyabb izomaktivitást mértek (18.1 \pm 9.1 és $18.5 \pm 12.2 \% \mathrm{MVC})$. Ez az eredmény a mi eredményeinktôl különbözik, mivel a m. rectus abdominis-nél egyértelmú fáradást figyeltünk meg míg az m. obliquus externus izomnál csak kismértékben jelent meg a mediánfrekvencia csökkenése. Escamilla és munkatársai az $\mathrm{m}$. rectus abdominis alsó részén ( $40 \pm 10 \% \mathrm{MVC}$ ) és a m. obliquus externus esetében $(40 \pm 20 \%$ MVC) viszont közel azonos izom aktivitást figyeltek meg. ${ }^{20}$ Ezek alapján arra következtethetünk, hogy a fent említett izmok mindenképpen jelentős szerepet játszanak a plank testhelyzet megtartásában. Pontos szerepük és jelentôségük felmérése a gyakorlatban még további vizsgálatot igényel. 
Az eredmények alapján a statikus gyakorlat alatt a gerinc helyzetének és görbületeinek, valamint az izmok aktiváció szintjének idôbeli változása, azaz a fáradás, mind kinematikailag, mind izom aktivációs oldalról kimutatható. A gerincszögek és az izmok medián frekvenciájának összevetése alapján például a 3. ábrán látható $40 \mathrm{~s}$ környéki TK billenés a m. gluteus maximus és a m. erector spinae iliocostalis hirtelen aktivitáscsökkenésével indokolható (5. ábra).

A teljes gyakorlat alatti izomfáradást a gerincgörbület változásával összevetve megállapítható, hogy érdekes módon csak a m. rectus femoris mutatott szignifikáns, nagymértékú korrelációt. Feltételezhetô, hogy egy ilyen hosszúságú gyakorlat során többször cserélődnek a jobban aktivált és éppen pihenô izmok, így is csökkentve a fáradást. Lehetséges, hogy az izmokat funkció szerint csoportosítva, ezen csoportok összegzett aktivitása már mutatna korrelációt a testtartás változásával.

Mivel a vizsgálat célja a mérési eljárás ellenôrzése volt, amelyet széles célcsoporttal kívántunk megtenni, a vizsgálat elsődleges korlátja az alacsony létszámú, erôsen inhomogén résztvevői csoport. További korlátot nyújtott, hogy csak felületi elektródákat használhattunk, így a mélyebb tartóiz- mok fáradását nem regisztrálhattuk.

A kutatás következő lépésében a létszámot növelve, homogén életkorú csoportokban folytatnánk a vizsgálatot. A vizsgálódás kiterjeszthetô más törzserốt mérô tesztekre is, mint például a Matthias-teszt. Fontos feladat az EMG regisztrátumon megjelenő, nem a motoros egységekból jövő jelek zajszûrési eljárásának tökéletesítése. További lehetôség a gerincalak folytonos megváltozása és az izomfáradás közötti kapcsolat meghatározásához keresztkorreláció számítása a gerincszögek és az mediánfrekvencia adatok között. Az analízis kiterjeszthetố oly módon, hogy az izmokat funkcionális csoportonként vizsgáljuk, így kimutathatóvá válhat az akaratlagos és akarat nélküli terhelésmegosztás az egyes tartóizmok között. Kiemelendő, hogy a módszer tovább fejleszthető tetszőleges ízületi szögek megváltozásának követésére is.

Összefoglalva megállapíthatjuk, hogy az izomfáradás elemzése kimutatta azon fóbb testtartásért felelôs izmok fáradását, amelyeket a plank-teszt megcéloz, míg a gerincgörbületi eredmények arra utalnak, hogy a lumbális gerincszakasz tartásának megváltozása lehet a teszt sikeres vagy sikertelen elvégzésének mutatója.

\section{IRODALOMJEGYZÉK}

\section{De Blaiser $C$, De Ridder $R$, Willems $T$, Vanden} Bossche L, Danneels L, Roosen P. Impaired Core Stability as a Risk Factor for the Development of Lower Extremity Overuse Injuries: A Prospective Cohort Study. Am J Sports Med. 2019;1-9.

2. Nesser TW, Huxel KC, Tincher JL, Okada T. The relationship between core stability and performance in division i football players. J Strength Cond Res. 2008;22(6):1750-4.

3. Betsch M, Wild M, Jungbluth P, Thelen S, Hakimi $M$, Windolf $J$, et al. The rasterstereographic-dynamic analysis of posture in adolescents using a modified Matthiass test. Eur Spine J. 2010;19(10):1735-9.

4. Ekstrom RA, Donatelli RA, Carp KC. Electromyographic Analysis of Core Trunk, Hip, and Thigh Muscles During 9 Rehabilitation Exercises. J Orthop Sport Phys Ther. 2007;37(12):754-62.

5. Tong TK, Wu S, Nie J. Sport-specific endurance plank test for evaluation of global core muscle function. Phys Ther Sport. 2014;15(1):58-63.

6. De Blaiser C, De Ridder R, Willems T, Danneels L, Vanden Bossche L, Palmans T, et al. Evaluating abdominal core muscle fatigue: As- 
sessment of the validity and reliability of the prone bridging test. Scand J Med Sci Sport. 2018;28(2):391-9.

7. Van den Tillaar R, Saeterbakken AH. Comparison of Core Muscle Activation Between a Prone Bridge and 6-RM Back Squats. J Hum Kinet. 2018;62(1):43-53.

8. Lark SD, Dickie JA, Faulkner JA, Barnes MJ. Muscle activation and local muscular fatigue during a 12-minute rotational bridge. Sport Biomech [Internet]. 2018;3141:1-12. Available from: http://doi.org/10.1080/14763141.2018.1433870

9. Schellenberg F, Schmid N, Häberle R, Hörterer N, Taylor WR, Lorenzetti S. Loading conditions in the spine, hip and knee during different executions of back extension exercises. BMC Sports Sci Med Rehabil. 2017;9(1):5-8.

10. Zemp R, List R, Gulay T, Elsig JP, Naxera J, Taylor WR, et al. Soft tissue artefacts of the human back: Comparison of the sagittal curvature of the spine measured using skin markers and an open upright MRI. PLoS One. 2014;9(4):1-8.

11. Schmid S, Studer D, Hasler CC, Romkes J, Taylor WR, Brunner R, et al. Using skin markers for spinal curvature quantification in main thoracic adolescent idiopathic scoliosis: An explorative radiographic study. PLoS One. 2015;10(8):1-12.

12. Takács M, Gál-Pottyondy A, Petró B, Rudner E, Váradi A, Kiss RM. Ultrahangalapú gerincvizsgáló eszközzel és optikaialapú mozgáskövető rendszerrel végzett gerincvizsgálatok eredményeinek összevetése. In: A Magyar Gerincgyógyászati Társaság 2019 évi Tudományos Ülése. 2019. p. 17-8.

13. Horváth M, Fazekas G. Metodikai összefoglaló mozgáskárosodás felmérése elektro- miográfiával - a kineziológiai emg. Ideggyogy Sz. 2003;56(11-12):360-9.

14. Yoshitake Y, Ue H, Miyazaki M, Moritani T. Assessment of lower-back muscle fatigue using electromyography, mechanomyography, and near-infrared spectroscopy. Eur J Appl Physiol. 2001;84(3):174-9.

15. Cifrek M, Medved V, Tonković S, Ostojić S. Surface EMG based muscle fatigue evaluation in biomechanics. Clin Biomech. 2009;24(4):327-40.

16. Hermens HJ, Freriks B, Disselhorst-Klug C, Rau $G$. Development of recommendations for SEMG sensors and sensor placement procedures. J Electromyogr Kinesiol [Internet]. 2000 [cited 2018 Aug 13];10(5):361-74. Available from: www. elsevier.com/locate/jelekin

17. Gál-Pottyondy A, Takács M, Petró B, Kisrákói $A$, Kiss D, Kiss RM. Egyperces statikus gyakorlatok alatt, optikai mozgáskövető rendszerrel végzett gerincvizsgálatok kineziológiai elektromiográfiával egybekötve. In 2019. p. 5-6.

18. Bohannon RW, Steffl M, Glenney SS, Green $M$, Cashwell L, Prajerova K, et al. The prone bridge test: Performance, validity, and reliability among older and younger adults. J Bodyw Mov Ther. 2018;22(2):385-9.

19. Czaprowski D, Afeltowicz A, Gebicka A, Pawtowska P, Kedra A, Barrios C, et al. Abdominal muscle EMG-activity during bridge exercises on stable and unstable surfaces. Phys Ther Sport. 2014;15(3):162-8.

20. Escamilla RF, Lewis C, Pecson A, Imamura R, Andrews $J R$. Muscle Activation Among Supine, Prone, and Side Position Exercises With and Without a Swiss Ball. Sports Health. 2016;8(4):372-9.

Hálásan köszönjük Dr. Takács Mária, Kisrákói Andrea és Kiss Dóra segitségét a mérések kivitelezésében. A kutatást az OTKA 115894 és a BME FIKP-BIO támogatta. Petró Bálintot jelen munka során az Emberi Eröforrások Minisztériuma, Új Nemzeti Kiválóság Program 18-3-I-BME-158 ösztöndija támogatta. 


\section{Dr. Kiss Rita M.}

Budapesti Múszaki és Gazdaságtudományi Egyetem, Mechatronika, Optika és Gépészeti Informatika Tanszék

H-1111, Budapest, Bertalan Lajos u. 4-6.

Tel.:(+36)1 463-1738 